\title{
The Space of Potential Conflict and Urban Spatial Justice: The Case of Johar Baru Subdistrict, Central Jakarta
}

\author{
Agustina M. Purnomo \\ Student of Doctoral Program of Socilogy \\ of Universitas Indonesia \\ email: agustina.purnomo@gmail.com
}

\begin{abstract}
The urban economic development that focuses on growth and privatization is marked by the growth of offices, trade and services in the city center leaving space for the poor in urban economic development space. The space of poverty produced by capitalist mechanisms and reproduced by the activities of the community groups within the space of poverty. The fact that Johar Baru subdistrict as a sub-district with the Potential Social Vulnerability Index and the Conflict Sensitivity Index located in the center of Jakarta's economic growth has demonstrated this phenomenon. Through qualitative methods with interviewing data collection techniques, observations, document studies and spatial representation in urban development planning, it was found that rioting is a representational practice of the dominance of spatial practice and practice representation at the macro level. Riot as a form of activity is build conflict-prone spaces as well as reinforces its position as a space designed by the production of urban space as a space of poverty.
\end{abstract}

Keywords: Johar Baru, Lefebvre, production of space, social justice, urban poverty space

\section{INTRODUCTION}

Central Jakarta Region is a strategic place in Jakarta Capital City Special Region (hereinafter referred to as Jakarta) that has economic and social advantages than other regions. Refers to National Central Bureau of Statistics (BPS) in 2016, has an increase in economic growth rate as measured from Gross Domestic Product (GDP) 2000 idrconstant price higher than other areas in Jakarta. Central Jakarta's economic growth in 2015 shows the highest increase compared to North Jakarta (5.61\%), West Jakarta (5.85\%), East Jakarta (6.08\%) and South Jakarta (4.96\%). Central Jakarta Region has some strategic place In Central Jakarta, if seen on the satellite map of Jakarta accessed at

www.streetdirectory.com, on May 25, 2017, there is growth in business space (Jl Thamrin, Jl Letjen Suprapto etc.) and leisure (golf course, horse racing, hotel), and socially has the symbol of the city center (National Monument/Monas), and the symbol of democracy of the nation, Indonesian Hotel Circle, the place where is people choose as a symbol of place of national demonstration.
In contrast, there are also areas with the highest Social Insecurity Potential Index (SIPI) in Jakarta (SIPI on 31.63 or light prone category) and there are four of the seven urban villages with the highest SIPI in Jakarta. The area is Johar Baru Sub-district, with all urban villages in Johar Baru subdistrict including seven areas with the highest SIPI in Jakarta. Galur urban village ranks first, Tanah Tinggi urban village ranks second, Johar Baru urban village ranks fifth rank and Kampung Rawa urban village ranks seventh (Jakarta Provincial People's Welfare Indicator, 2016).

In line with BPS data, data released by Jakarta National Unity and Politics Board in collaboration with University of Indonesia indicate Johar Baru sub-district, especially Kampung Rawa urban village with the highest conflict susceptibility index in Jakarta and became the only urban village to reach conflict index score exceeding 60 in Central Jakarta. Three other urban villages are located in North Jakarta. Kampung Rawa urban village has a population density index and a brawling index reaches 100.00 or if confirmed on the calculation formula conducted by Jakarta National Unity and Politics Board, achieving maximum value of population density indicator and brawl in Jakarta (Jakarta National Unity and Politics Board Jakarta Province, 2016).

The SIPIscore of Johar Baru sub-district shows a space with poverty vulnerability index, environmental and health vulnerability index, physical infrastructure vulnerability index, social capital vulnerability index, highest security vulnerability index for Jakarta. In other versions submitted by Jakarta's National Unity and Density Board (2016) the Vulnerability Conflict Index score of Johar Baru sub-district indicates poor household index, population density index, slum Citizen Associationindex, crime index and high brawl index. This shows the phenomenon that liberalist warned as the impact of urban development in the form of localization of the urban poor. An area or city space that is vulnerable to crime, poverty, and subsequent poverty reproduction (Gottdiener and Hutchison, 2011).

\section{A. Problem Statement}

The fact that conflict-prone areas are at the center of urban economic growth has been reminded by Gottdiener and Hutchison (2011) that development with the spirit of 
modernization has consequences for privatization, handing over development to market mechanisms and business interests that often fail to bring social justice for the poor and the minorities (p.355). The idea of development becomes too technocratic, too material-oriented, and seeing human beings as objects of development (Wirutomo, 2014). The focus of development on modernity produces polarization or spatial disparities in different living space opportunities for metropolitan populations. The form of social injustice is evident in the spatial competition occurring between space for public and private investment in the limited urban space.

The establishment of business spaces in the city center or in the research of Manuel-Navarrete and Redclift (2012) in the form of tourism consumer space develops segregation of space as a result of the process of industrialization of tourism and urbanism. Both processes led to the consumption of urban space and left room for the urban poor and placed the urban poor in a space characterized by poverty, slums, and density. It is represented by Johar Baru Subdistrict as a space for the urban poor in Central Jakarta.

Lefebvre (2004) introduces a triadic dialectic on perceived-conceived-lived space to explore complex activities in which injustice is defined, amplified and altered. Furthermore, according to Lefebvre (2004), the study of space production can be examined in three levels; local, national and global. Adapting Cristie's research (2013), at the macro level (national and global) the pattern formed is explained by globalization where space arrangements are left to the free market. At the level of the city government, space is produced by the interests of capitalism, showed by government policy in the regulation of urban space that binds the urban poor in structurally unfair spaces. At the local level, the production of space is seen from how society builds the production of space through their reality in the develoved space, their representation in space and their daily practice as experience and expression in and to the formed space. Lefebrve sees local-global interaction as a dynamic, plays in policy and practice and he also sees the production of space as a form of injustice production.

Referring to the Lefebvre space production framework, the researchs are conducted by Manuel-Navarrete and Redclift (2012) and Cristie (2013), this study will focus on addressing how conflict-prone areas are produced within the urban growth centers? The research will look at the macro level (city) and meso level (Johar Baru community). At the meso level, the research will focus on groups of brawlers in Johar Baru sub-district.

\section{B. Conceptual Framework}

The socio-spatial approach that explains the social injustices generated by modernization as proposed by Gottdiener and Hutchison (2011) describes the process of space production at the macro level, the production of urban space is influenced by the interests of the government and the government's partisanship in business driven by local and global markets which are controlled by the private sector. The same approach was put forward by Soja (2009) and Harvey (1989). At the macro level, the government's interest in the form of government policy builds the accepted urban spaces as a reality of urban space is conceptualized in the form of urban spatiallayout, building forms and space purposesand experiencse on the space in the form of daily practice of people (Lefebvre, 2003). This concept of spatial practice, practif of representation and representational practices is the basis of Lefevre's triadic conception of perceived-conceived-lived of space.

In its approach, Lefebvre does not specifically distinguish macro levels with meso. Lefebvre does not see the macro level affecting the meso level and vice versa. According to him, social space including local places is a multiple movement "embracing..... individual entities and peculiarities, relatively fixed points, movements, and flows and waves-some interpenetrating, others in conflict and so on "(Lefebvre, 1991, p. 88). Locale may never appear in a nationalor global space but is continuously present. Lefebvre's polytmic approach emphasizes the relationship between local and global interconnected, crossed, interrupt or interrupted or in Lefebvre's terms of hypercomplexity interaction.

Lefebvre also stressed that space, time and energy are forms of social formation. All are social orders. "Space as a synchronic order, time as diachronic order and energy as reality for social formation" (Lefebvre, 1991:13). The triadic dialectic of Lefebvre is to see how societies construct their space and time, how power and relationships produce in space and time, knowledge and everyday meaning. Social space is in a continuous network of relationships actively produced and produced within a time frame.

For the purposes of analysis, the triadic dialectics of Lefebvre focuss on meso level, or Johar Baru sub-district level by focusing on the process of spatial practice, spatial practice, practif of representation and representational practices or perceived-conceived-lived practices of develoving space. The focuss is done to gain an in-depth understanding of the space production process taking place at the Johar Baru community level. 
Figure 1 :Form of analysis to be performed as shown in the following

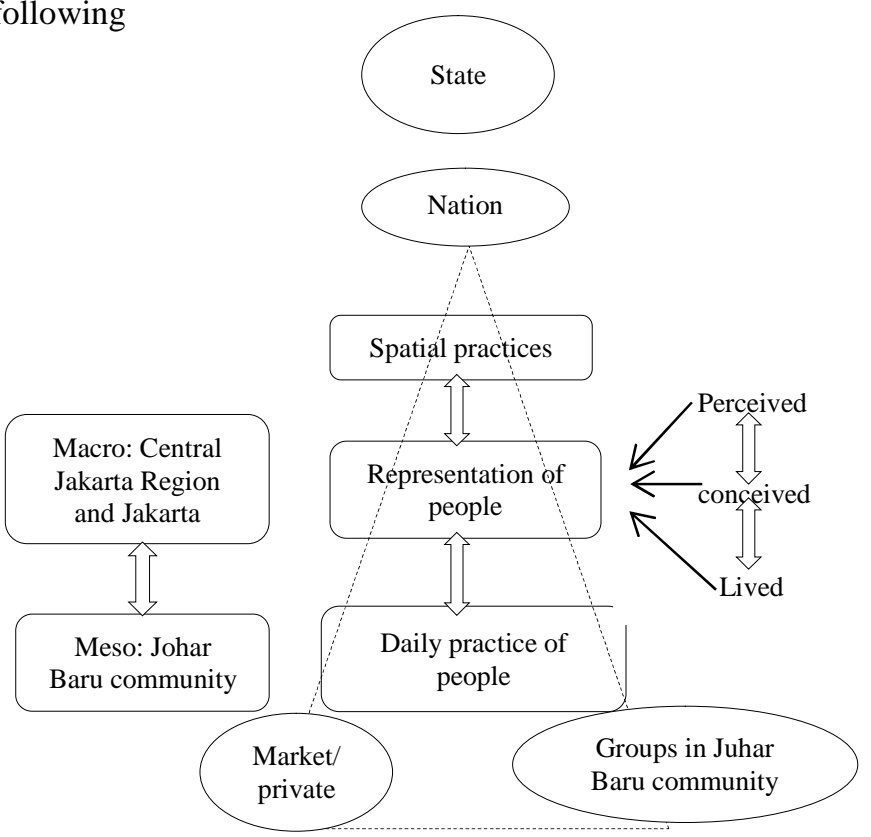

Fig. 1. Konseptual Framework

\section{RESEARCH METHOD}

The research was conducted by qualitative method with research data obtained from document tracking and interview. Document search was performed using online searches on Central Bureau of Statistics data of Jakarta, Central Jakarta and other areas in Jakarta, satellite location map search presented by www.streetdirectory.co.id, www.googlemaps.com and previous studies review. Interview data were obtained from interviews conducted in $2013^{1}$.

Location of research selection was puposived in accordance with the objectives of the study. Johar Baru subdistrict was chosen because it is located in the center of Jakarta and has the appropriate characteristics (as presented in the introduction). Community groups of brawlers are identified through on-site observations and interviews.

\section{FINDING AND DISCUSSION}

In the macro level, Central Jakarta Region which is in the province of Jakarta area, the capital city of Indonesia, shows spatial practice that can be seen from the city spatial policy. Detailed Jakarta Spatial Plan Map 2011-2030 shows that most of Central Jakarta area is for office, trade and service area. Johar Baru sub-district mostly goes to this

${ }^{1}$ Interview did by student of Magister Program of Sociology Indonesia University in December 2013 designation area and a small part goes into residential areas (seen from the scale of map composition in ficture 2). On the actual use of space, based on the observation of Johar Baru sub-district directly adjacent to the primary arterial road (Jalan Letjen Suprapto) and on the side of the road is filled with shop houses, wholesalers, mini-markets, restaurants and cafes,mall, non star hotels till the 4-stars hotels. The area between settlements there are small streets, which on the side of the road filled with small traders, mini markets, restaurants, informal sectors and shops. Dense settlements are in the middle. On the other side of Johar Baru Subdistrict is bordered by densely populated areas of Cempaka Putih Subdistrict, Cikini, Kramat and Senen, which have similar characteristic with Johar Baru Subdistrict.

As part of the metropolitan city of Jakarta, the reality of the Johar Baru poor space in the central office space, trade and services of the capital shows a contradictory pattern. On one side of the urban space built with the features of modernity, the economic development of large capital visible from the shape of the building (modern architecture), comfort (air-conditioned, spacious, green), enjoyed by city executives (wealthy, well-dressed and having a steady income) money circulation and high daily activity (traditional markets, wholesale centers, offices, shophouses, restaurants and malls). Meanwhile, the representation of Johar Baru youth groups in the urban space is absent. Based on interviews, the youths in the group were mostly primary school educated, drop out, junior high and high school who did not work or worked as office cleaning or office boy in the offices around Johar Baru. The expression and the daily activities of modern urban space do not provide space for them.

At the meso level, it was found that vulnerable groups that are considered the main cause of high conflict vulnerability index in Johar Baru are groups of young people who are members of the ganks of young people. It was identified that there were at least five ganks, namely Gempal gank (Gempal Pangkalan), Kopar gank (Kota Paris), Baladewa gank, Golday gank, and Bodrex gank (Bocah Direktur). From depth interviews, it was concluded that what caused them to fight according to their own opinion is the habit of hanging out or in local language known as nongkrong ${ }^{2}$.

The five ganks have an intense hangout habits and every brawl occurred involving gank and youth who are hanging out in the gank. The habit of hanging out alone wasdoingbecause they had no special activity to do, no

\footnotetext{
${ }^{2}$ Nongkrong is a term to be together in a group / gank without doing any special activity to deliberately do
} 
job/fixed school, working or going to school but merged with gank after working or schooling home, and a narrow home environment is not comfortable to stay for long at home (observed in figure 3 and 4). Through this hangout, youth gang members start getting to know liquor and drugs. Hanging out is also the beginning of brawl because through hanging out, the activity that ignited the brawl happened, the closeness between the members of the genk was getting closer and the courage to brawl was build. An interview with $\mathrm{Cang}^{3}$ Arfan (head of the Baladewa gank) was showing this:

"When the youngmember of Baladewa gank are hanging out, they usually fancy, when a girl passing is cursed by on the "hi bitch", when a guy passing is cursed "hi dog", from there when the person who is not accepted usually goes to a friend and ask help to his gank, and they will come with the gank directly pay resentment to baladewa gank".

Hanging out, as the beginning of the brawl is a daily activity of groups of youth who became their life dives. A narrow house and on average occupied by more than one nuclear family causes them to have no place in their own homes. Hangout or known by tongkronganis being home to them.

"The condition of a narrow house can not accommodate all family members. When their parents are asleep, the children must be outdoors and their friends are the "home" for them. Interaction with parents becomes limited and children were growing up with their friends outside the home. Since childhood the children play outside the house, when they were getting older they were playingin their tongkrongan ........... They feel their tongkrongan is their home and their friends are their family. "(Tyo, Chairman of Youth Organization of Johar Baru Urban Village).

Tongkrongan space built in their daily experience as a home. Cursing people through and accepting the consequences in the form of brawl is being activities that are usually did as members of the tongkrongan space. Space defined as violence by outsiders is defined as cohesiveness and togetherness for gank members. His own home did not build on the experience and activities as a home because of the representational practice of the house is only as a residence for young gank members. A row house designed for New Johar residents by government is inadequate as a house because it is narrow and does not provide the rooms of a family togetherness. This can be seen in figure 5 and 6 . Gank and hangout as representative spaces are accepted where the hangout is 'actual house' and gank friend as 'real family'. Johar Baru's spatial practice as conflict-prone is produced and produces representation practices and representational practices. Slums, poverty and density produce tongkrongan as 'home', tongkrongan produce 'space riots' and space riot produces sustainability of poverty, subsequent slums and density or built now.

The present poor, densely packed and degraded residential spaces (or in Lefebvre's terms 'produced') due to urban development policies and at the community level, ganks produce poverty space into conflict-prone spaces through brawl. Referring to Gottdiener and Hutchison (2011), governmental alignments to private investors always leave the most vulnerable spaces both from environmental damage (observable in figure 7 and 8) as well as mentally damage to the urban poor and minority people. The people who facilitated in the city's business space are merely middle-class, highly educated and skilled. ManuelNavarrete and Redclift (2012) studies was indicate the bargaining position of urban poor in urban development can be encouraged by organizing and involving communities in development planning. However, Cristie's study (2013) found that in education, the production of space is perpetuated not only by the government, but by the underlying structures such as the teacher and by the black community it self in the form of localization reinforcement due to the later social problems. Cristie's research (2013) seems to be relevant to the Johar Baru case.

\footnotetext{
${ }^{3}$ Cang is a name for Uncle in Betawi Language
} 


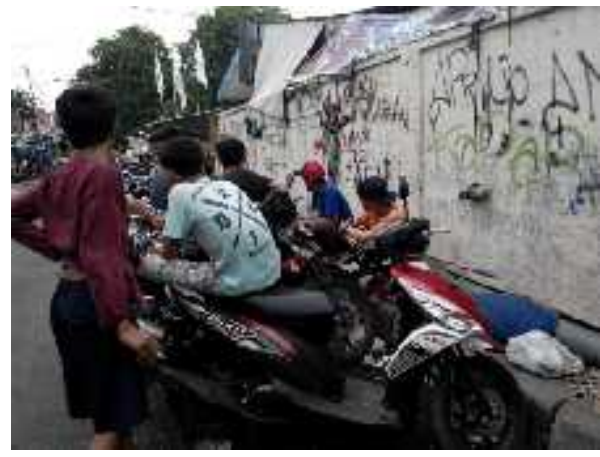

Fig. 3. Kopar Gank Tanah Tinggi Urban Village

Source: Research in 2013

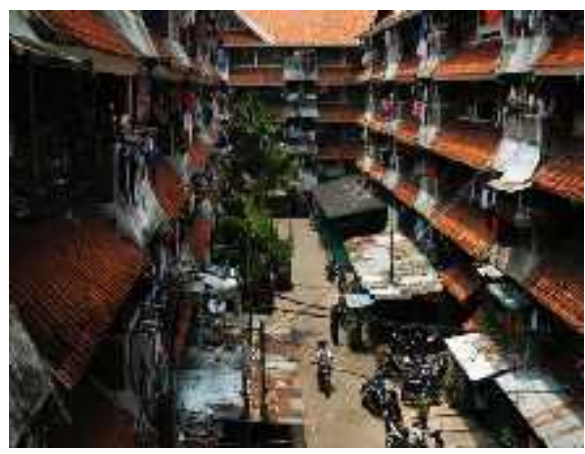

Fig. 6. Row Housing in Tanah Tinggi Urban Village

Source: www.suaramerdeka.com

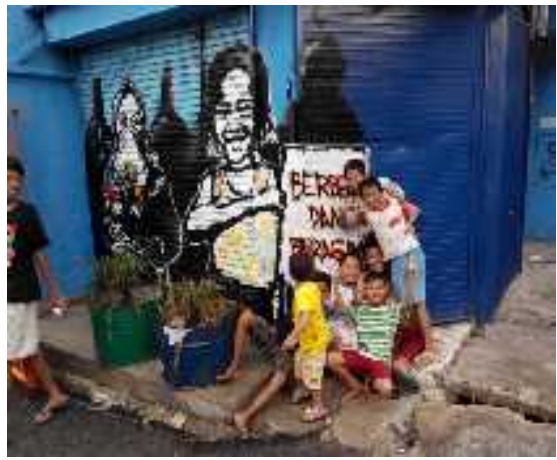

Fig. 4. Hanging out habit start from kids

Source: Research in 2013

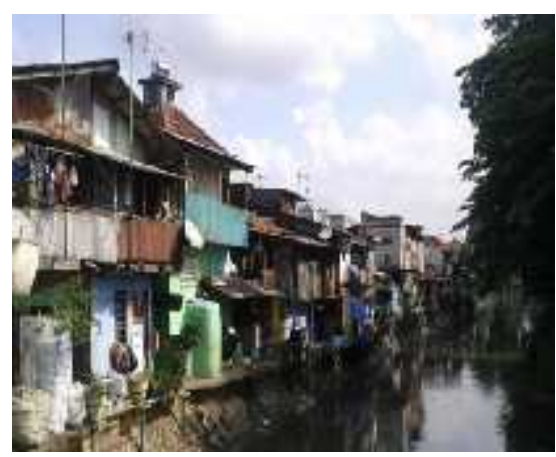

Fig. 7. Living environment in Johar Baru Sub-district

Source:kampungderetjoharbaru.wordpr ess.com

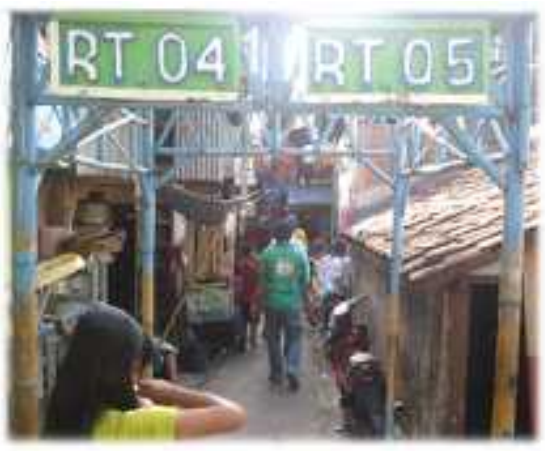

Fig. 5. High tension brawl place Source:kampungderetjoharbaru.wordpr ess.com

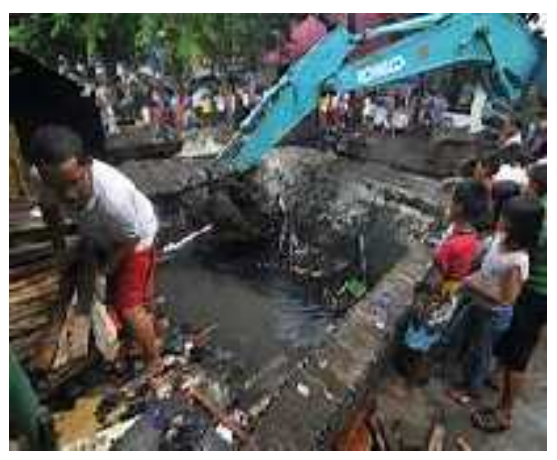

Fig. 8. Living environment in Johar Baru Sub-district

Source:kampungderetjoharbaru.wordpr ess.com 
Johar Baru Community School (SKJB), creativity studio, citizen dialogue with Mayor of Central Jakarta in research in 2013 did not stop the brawl that still happened in 2014 (www.liputan6.com), year 2015 (www.kompas.com), 2016 (www.liputan6.com).

\section{Conclusion and Recommendation}

Referring to the results of this study, Johar Baru as a conflict prone space will continue to be produced while urban development leaves poverty spaces as a result of sediment from market-oriented development. The formation of the space of the poor is a dominant spatial practices, a process used by social elites in achieving and maintaining dominance through social practices. Spatial representation not only dominates spatial practice, but also representational practices. Johar Baru, which developed into a conflict-prone space, reinforces what Lefebvre has to say about representational space formed by the experience of people who instead become revolutionary forces instead become the amplifier of spatial representation because of hegemony (Ritzer, 2016). Spatial practice by gank brawlers only the hegemony of economic power applied through urban development. The forms of evictions and relocations that are often used as solutions (published in www.metrotv.news) are a form of spatial practice that reinforces is increasingly pressuring the urban poor and replacing it with the urban working class with representational space that is more suited to the mode of production of urban development.

At this stage, development by emphasizing the inclusive society through development processes that strengthen the basic elements of socio-cultural life called structures, cultures and processes (Wirutomo, 2014) can be an alternative to break the production process of space prone to the Johar Baru conflict. This approach cuts the basic assumption of Jakarta's development that produces a new Johar conflict space, oriented to economic development alone. To borrow Wirutomo's (2014) approach the recommendation of this research is to build a more balanced power relationship between government and society, build community involvement and desire to change from communities and build opportunities for people to improve their lives through empowering communication processes. At this level, the representation of urban poor in urban spatial policy is not only limited to residential spaces (eg in the form of row housing, see figure 6), but to the development of spaces that allow communities to make solidity groups hang out into an empowering communication space. The dialogue forum that has been done by the Mayor of Central Jakarta can be the beginning of the relation of the society-the government which has to be followed by the development and the urban spatial policy that pay attention to the quality of people's life.

\section{Acknowledgement}

Part of qualitative data taken from interview data has been did by Eko Wahyono, Arman, Hendri, Guspur and Mala in 2013. The data were using as permission. High appreciate for allowing their interview transcrift to be used as one of source qualitative data of this paper.

\section{References}

1. Badan Kesatuan Bangsa dan Politik Provinsi DKI Jakarta, Peta Kawasan Rawan Konflik Provinsi DKI Jakarta : Jakarta Selatan, Jakarta Timur, Jakarta Barat, Jakarta Pusat, Jakarta Utara (Badan Kesatuan Bangsa dan Politik Provinsi DKI Jakarta, 2015).

2. Biro Pusat Statistik DKI Jakarta, Indikator Kesejahteraan Rakyat Provinsi DKI Jakarta 2016 (Biro Pusat Statistik DKI Jakarta, 2016).

3. Biro Pusat Statistik Jakarta Pusat, Pertumbuhan Ekonomi Jakarta Pusat Tahun 2015 (Berita Resmi Statistik Kota Jakarta Pusat No. 01/10/Th XVI, Oktober 2016).

4. P. Christie, Space, Place, and Social Justice: Developing a Rhythmanalysis of Education in South Africa, Qualitative Inquiry 19(10) (2013) 775-785.

5. M. Gottdiener and R. Hutchison, The New Urban Sociology, $4^{\text {th }}$ ed. (Westview Press, Boulder, 2011).

6. D. Harvey, From Managerialism to Entrepreneurialism: The Transformation in Urban Governance in Late Capitalism, Geografiska Annaler, Series B, Human Geography, Vol. 71, No. 1, The Roots of Geographical Change: 1973 to the Present (1989), 3-17.

7. H. Lefebvre, The production of space (D. Nicholson-Smith, Trans, Oxford, UK: Blackwell, 1991).

8. H. Lefebvre,. Rhythmanalysis: Space, time and everyday life (S. Elden \& G. Moore, Trans, London, England: Continuum, 2004).

9. D. Manuel-Navarrete and M. Redclift, Spaces of consumerism and the consumption of space: tourism and social exclusion in the 'Mayan Riviera', Consumer Culture in Latin America (2012), 177-193.

10. G. Ritzer. Teori Sosiologi Modern, $7^{\text {th }}$ ed. (Jakarta [ID]: Kencana, 2016).

11. E. W. Soja, Seeking Spatial Justice (Globalization and Community Series. University of Minnesota Press, 2010).

12. P. Wirutomo, Sociological Reconceptualization of Social Development: With Empirical Evidence from Surakarta City, Indonesia. Asian Social Science, Vol. 10, No. 11 (2014).

13. http://print.kompas.com/baca/2015/10/19/Tawuran-KembaliTerulang-di-Johar-Baru

14. http://foto.metrotvnews.com/view/2016/05/02/522291/rencanapenggusuran-permukiman-johar-baru

15. http://news.liputan6.com/read/2510773/tawuran-antarwargapecah-3-kali-di-johar-baru 